\title{
Flexible mating system in a logged population of Swietenia macrophylla King (Meliaceae): implications for the management of a threatened neotropical tree species
}

\author{
Maristerra R. Lemes · Dario Grattapaglia • \\ James Grogan · John Proctor · Rogério Gribel
}

Received: 21 February 2007 / Accepted: 22 May 2007 / Published online: 19 June 2007

(C) Springer Science+Business Media B.V. 2007

\begin{abstract}
Microsatellites were used to evaluate the mating system of the remaining trees in a logged population of Swietenia macrophylla, a highly valuable and threatened hardwood species, in the Brazilian Amazon. A total of 25 open pollinated progeny arrays of 16 individuals, with their mother trees, were genotyped using eight highly polymorphic microsatellite loci. Genotypic data analysis from the progeny arrays showed that 373 out of the 400 seedlings $(93.25 \%)$ were unambiguously the result of out-
\end{abstract}

M. R. Lemes $(\bowtie) \cdot$ R. Gribel

Laboratório de Genética e Biologia Reprodutiva de Plantas, Instituto Nacional de Pesquisas da Amazônia, Avenida André Araújo, 2936, Manaus, AM 69083-000, Brazil

e-mail: mlemes@inpa.gov.br

M. R. Lemes · J. Proctor

School of Biological and Environmental Sciences,

University of Stirling, Stirling FK9 4LA, Scotland, UK

D. Grattapaglia

Laboratório de Genética de Plantas, EMBRAPA-Recursos Genéticos e Biotecnologia, C.P. 02372, Brasília, DF

70770-900, Brazil

J. Grogan

Yale University School of Forestry and Environmental

Studies, 360 Prospect Street, New Haven, CT 06511, USA

J. Grogan

Instituto do Homem e Meio Ambiente da Amazônia (IMAZON), Rua Domingos Marreiros, 2020, Bairro

Fátima, Belém, PA 66060-160, Brazil crossed matings and that the remaining $6.75 \%$ had genotypes consistent with self-fertilisation. Apomixis could be ruled out, since none of the 400 seedlings analysed had a multi-locus genotype identical to its mother tree. The high estimate of the multi-locus outcrossing rate $\left(t_{m}=0.938 \pm 0.009\right)$ using the mixed mating model also indicated that the population in this remnant stand of $S$. macrophylla was predominantly allogamous. The relatively large difference between the multi-locus and single-locus outcrossing estimates $\left(t_{m}-t_{s}=0.117 \pm 0.011\right)$ provides evidence that, in spite of the high outcrossing rate, a considerable degree of biparental inbreeding has contributed to the genetic structure of this population. Levels of outcrossing were not evenly distributed among maternal trees ( $t_{m}$ ranging from 0.39 to 1.00$)$, suggesting the occurrence of a variable degree of selfincompatibility and/or dichogamy among individual trees of this monoecious species. Due to its generalist pollination system and some level of tolerance for selfing, S. macrophylla seems to be resilient to environmental disturbances such as those caused by logging, since it sets fruits with predominantly outcrossed seeds even at low stand densities. Therefore, the remaining individuals in logged areas or in relict fragments may be very important for long-term population recovery and genetic conservation programmes.

Keywords Amazon - DNA microsatellites - Genetic conservation - Genetic diversity · Mahogany · Outcrossing 


\section{Introduction}

The mating system determines how the transition of genotypic frequencies in a population occurs from one generation to the next (Ritland 1988). The classification of the mating system in plants is based on the genetic relatedness between the male and female gametes (derived from the pollen and ovule, respectively) in the newly formed zygotes (Ritland 1983). The mating system can be characterised in terms of the proportion of mature seeds resulting from selfing or outcrossing events (Murawski and Hamrick 1991). The mating system is an important factor in determining how genetic variation is distributed among subdivisions of a population and among individuals in those subpopulations, as well as among progenies, with a direct impact on the long-term maintenance of genetic variation in existing populations. The susceptibility of a population to the loss of genetic diversity and inbreeding depression following for example logging or habitat fragmentation will depend, to a considerable extent, on the characteristics of its mating system.

The pattern of mating in tropical trees is complex, reflecting the influence of several genetic and ecological factors such as the demography of adult trees, flowering intensity, synchrony of flowering among and within individuals, the nature and intensity of selfincompatibility mechanisms, the foraging behaviour of pollinators, and the selective abortion of young fruits. Although many plant populations and species appear to produce mixtures of selfed and outcrossed progeny (Barrett and Husband 1990), most tropical tree species appear to exhibit morphological and physiological adaptations, which promote outcrossing and prevent or reduce selfing (Bawa 1990). As a result, the mating system of the majority of neotropical trees investigated so far by using molecular markers, such as allozymes or DNA microsatellites showed predominant or complete outcrossing (see review in Ward et al. 2005). Additionally, a number of studies have shown that inbreeding of biparental origin is frequently very low or undetectable among tropical trees, at least with isozyme markers (Eguiarte et al. 1992; Murawski and Hamrick 1992a, b; Hall et al. 1994; Boshier et al. 1995; Doligez and Joly 1997; James et al. 1998; Loveless et al. 1998). These findings contrast with previous ideas that autogamy and inbreeding would be favoured in widely spaced conspecific tropical forest trees (Fedorov 1966). Based on data available so far, species of fast growing, gap-colonising tropical trees with light-requiring juveniles and adults persistent in the mature forestexamples include the malvaceous Ceiba pentandra $\mathrm{L}$. Gaertner and Cavanillesia platanifolia (Bonpl.) Kunth, the legumes Senna multijuga (Rich.) H. S. Irwin \& Barneby and Dinizia excelsa Ducke, and Cariniana legalis (Mart.) Kuntze (Lecythidaceae)—-tend to be somewhat tolerant to selfing (Murawski and Hamrick 1991; 1992a, b; Murawski et al. 1994; Gribel et al. 1999; Dick 2001; Ribeiro and Lovato 2004; Sebbenn et al. 2000).

The conservation status of Swietenia macrophylla King (Meliaceae) has been the subject of increasing concern due to over-exploitation of this species by selective logging and increasing habitat destruction (Grogan and Barreto 2005). Despite the high socioeconomic importance of $S$. macrophylla, information on the processes maintaining genetic variation in natural populations of this species is scarce. Studies on the population genetics of $S$. macrophylla have focused mainly on estimates of genetic diversity and population structure in Central and South America and implications for its conservation (Gillies et al. 1999; Lemes et al. 2003; Novick et al. 2003).

In this study, the outcrossing rate $\left(t_{m}\right)$ and other mating system parameters $\left(t_{s}=\right.$ the single-locus population outcrossing rate, $F=$ the single-locus inbreeding coefficient of maternal parents, and $r_{p}=$ the correlation of paternity) were estimated for a population of $S$. macrophylla in the Brazilian Amazon, using eight highly polymorphic microsatellite loci (SSR - simple sequence repeat). The main aims were to understand how the mating system may contribute to shaping and maintaining the levels of genetic variation of the population and to infer how logging and habitat fragmentation may affect the reproduction of remaining individuals and the recovery capacity of the population. These findings, coupled with information on pollination and seed dispersal mechanisms, have important implications for the long-term conservation and management of this valuable hardwood species.

\section{Materials and methods}

Study site

Field work was conducted at the Marajoara Management Project site $\left(c .07^{\circ} 50^{\prime} \mathrm{S}, 50^{\circ} 16^{\prime} \mathrm{W}\right)$ in southeast 
Pará State, Brazil. The project site of about 4,100 ha $(13 \times 3.15 \mathrm{~km})$ of selectively logged forest was subdivided into 12 plots of approximately 340 ha each $(1.08 \times 3.15 \mathrm{~km})$. Samples for the present study were collected from trees randomly selected in plots 1,2 , and 3 (c. 1,020 ha) at the northern end of the project area. These plots were selectively logged between 1992-1994 at a relatively low intensity because the intended showcase status of the management project. Even so, a full inventory covering an area of 204 ha within the study area at Marajoara demonstrated that only $16 \%$ of commercial-sized trees $(\geq 45 \mathrm{~cm}$ diameter at breast height (dbh) at the time of cutting) remained after logging, compared to $c$. $8 \%$ survival after conventional logging (and $\leq 5 \%$ survival by trees $>60 \mathrm{~cm} \mathrm{dbh}$, the current legal minimum cutting limit for mahogany; Grogan et al. in press). Stand density of mahogany trees $\geq 45 \mathrm{~cm}$ dbh was therefore reduced from approximately one tree per 2 ha $\left(0.51 \mathrm{ha}^{-1}\right)$ to one tree per $12 \mathrm{ha}\left(0.08 \mathrm{ha}^{-1}\right)$. Within the study area, Swietenia macrophylla is nearly always found at highest densities along the banks of small seasonally dry streams and in adjacent lowlying, flat areas with poorly drained soils, sharing this habitat with the palm species Orbignya phalerata Mart. and Maximiliana maripa (Aublet) Drude (Grogan and Galvão 2006). It is usually not found in the denser and taller upper slope or middle slope forest communities.

Sampling and genetic analysis

Seeds and leaves were collected from 25 adult trees of Swietenia macrophylla in the study area. Seeds from a given tree were sampled from the same capsule. We collected the capsules directly from the crown of each mother tree. We avoided seed collections beneath the trees in order to exclude interference of factors such as low-density seedfall, putative conspecific inter-tree wind dispersal, transport by animals, and low viability due to pathogen attacks. As most of the 25 sampled trees had only one capsule at the proper maturation stage in the crown, seeds were sampled from one capsule per tree and germinated in a greenhouse. Genomic DNA was extracted from the leaves of 400 seedlings of 25 open-pollinated families (16 seedlings/family) and the 25 maternal trees using a standard CTAB procedure (Doyle and Doyle 1987). All seedlings and mother trees were genotyped at eight highly polymorphic microsatellite loci previously developed and optimised in multiplexed fluorescence-based systems for Swietenia macrophylla (Lemes et al. 2002).

Microsatellite amplification was carried out in a final volume of 10 or $25 \mu \mathrm{l}$ for single and multiplexed reactions, respectively, containing $1.25-2.0 \mu \mathrm{M}$ of each forward and reverse primer, 1 unit Taq DNA polymerase, $200 \mu \mathrm{M}$ of each $\mathrm{dNTP}, 1 \times$ reaction buffer $(10 \mathrm{mM}$ Tris- $\mathrm{HCl}, \mathrm{pH} 8.3,50 \mathrm{mM} \mathrm{KCl}$, $\left.1.5 \mathrm{mM} \mathrm{MgCl}_{2}\right)$, BSA $\left(2.5 \mathrm{mg} \mathrm{ml}{ }^{-1}\right), 5.0 \mathrm{ng}$ of template DNA, and distilled ultrapure $\mathrm{H}_{2} \mathrm{O}$. Amplifications were performed using a MJ Research PTC100 thermal controller using the following program for all loci: an initial denaturation at $96^{\circ} \mathrm{C}$ for $2 \mathrm{~min}$, followed by 30 cycles of $94^{\circ} \mathrm{C}$ for $1 \mathrm{~min}, 56^{\circ} \mathrm{C}$ for $1 \mathrm{~min}$, and $72^{\circ} \mathrm{C}$ for $1 \mathrm{~min}$, and a final elongation step at $72^{\circ} \mathrm{C}$ for $7 \mathrm{~min}$. PCR products were electrophoresed on a $5 \%$ denaturing polyacrylamide gel in an ABI Prism 377 sequencer. GeneScan and Genotyper software (Applied Biosystems Inc.) were used for data collection and allele size estimation.

Data analysis

The inbreeding coefficient $(f)$ at each locus for the parent and seedling generations was calculated by the formula $f=1-\left(H_{o} / H_{e}\right)$, where $H_{o}$ is the observed proportion of heterozygotes and $H_{e}$ is the expected heterozygosity under Hardy-Weinberg equilibrium. Deviations (excess or deficiency) of heterozygotes in adults and seedlings from the Hardy-Weinberg proportions were tested by calculating the U-test (Raymond and Rousset 1998) and the inbreeding coefficient (Weir and Cockerham 1984) using Genepop version 3.1.b program (Raymond and Rousset 1998). Estimation of exact $p$ values was determined by the Markov chain method (Guo and Thompson 1992).

Mating system analysis was based on the mixed mating model of Ritland and Jain (1981) by using the multi-locus mating system program MLTR 3.0 (Ritland 2002). The MLTR estimation method is based on the maximum-likelihood procedure (Ritland and Jain 1981; Ritland and El-Kassaby 1985). The expectation-maximisation method was used for maximising the likelihood equation for both population and individual family estimates. The MLTR program 
estimated the following mating system parameters: multi-locus outcrossing rate $\left(t_{m}\right)$, minimum variance single locus outcrossing rate $\left(t_{s}\right)$, average single locus inbreeding coefficient of maternal parents $(f)$, correlation of outcrossing rate within progeny arrays $\left(r_{t}\right)$, correlation of outcrossed paternity within progeny arrays $\left(r_{p}\right)$, and gene frequencies of the pollen and ovule pools $(p)$. The paternity correlation $\left(r_{p}\right)$ is equivalent to the probability that any two randomly chosen outcrossed seeds were sired by the same father (Ritland 1989). Therefore, $r_{p}$ is inversely related to the number of outcross parents $(n)$ by $r_{p}=1 / n$, where $n$ is the effective number of pollen donors. Variances of the mating system parameters were estimated by bootstrapping, by re-sampling individuals within progeny arrays 1000 times. If a high number of polymorphic loci are used in the analysis, as in the present study, multi-locus estimates tend to be robust and violations of the assumptions of the mixed-mating system model have a minor impact on estimates of the mating system parameters (Ritland 2002). Due to the use of eight hypervariable loci, the outcrossed seeds were directly identified based on the presence of at least one locus with a different allele from those present in the mother tree.

\section{Results}

Genetic diversity in adults and seeds

All 25 adult trees and their 400 offspring were genotyped for the eight SSR loci developed for Swietenia macrophylla. All offspring had at least one maternal allele, suggesting typical diploid Mendelian inheritance at all loci and showing no evidence of null alleles in this population.

Data on number of alleles, expected and observed heterozygosities, and inbreeding coefficient per locus for the adult and seedling cohorts are shown in Table 1. The number of alleles per locus ranged from 4 to 13 (mean 9.2) among the seed parents and from 8 to 19 (mean 14.2) among the offspring seedlings. The expected heterozygosities were similar $(0.79)$ for both adult and offspring stages. No excess of heterozygotes (i.e. significantly negative $f$ ) was found

Table 1 Genetic diversity for adult and offspring cohorts of Swietenia macrophylla at Marajoara, south-eastern Amazonia, Brazil, using eight microsatellite loci

\begin{tabular}{|c|c|c|c|c|c|c|}
\hline Locus & Generation & $\mathrm{N}$ & Number of alleles & $\mathrm{He}$ & Ho & $\mathrm{f}$ \\
\hline \multirow[t]{2}{*}{ sm01 } & Parents & 25 & 13 & 0.904 & 0.920 & $-0.018^{\mathrm{ns}}$ \\
\hline & Offspring & 393 & 17 & 0.903 & 0.832 & $0.079 * *$ \\
\hline \multirow[t]{2}{*}{$\operatorname{sm} 22$} & Parents & 25 & 9 & 0.826 & 0.720 & $0.131^{\mathrm{ns}}$ \\
\hline & Offspring & 398 & 17 & 0.822 & 0.724 & $0.119^{*}$ \\
\hline \multirow[t]{2}{*}{ sm31 } & Parents & 25 & 13 & 0.914 & 0.840 & $0.083^{*}$ \\
\hline & Offspring & 398 & 19 & 0.911 & 0.894 & $0.018 * * *$ \\
\hline \multirow[t]{2}{*}{$\operatorname{sm} 32$} & Parents & 25 & 10 & 0.899 & 0.880 & $0.021^{\mathrm{ns}}$ \\
\hline & Offspring & 396 & 14 & 0.891 & 0.828 & $0.071^{* *}$ \\
\hline \multirow[t]{2}{*}{$\operatorname{sm} 40$} & Parents & 25 & 10 & 0.749 & 0.840 & $-0.125^{\mathrm{ns}}$ \\
\hline & Offspring & 394 & 14 & 0.781 & 0.708 & $0.093 * * *$ \\
\hline \multirow[t]{2}{*}{$\operatorname{sm} 46$} & Parents & 25 & 8 & 0.834 & 0.760 & $0.091^{\mathrm{ns}}$ \\
\hline & Offspring & 392 & 11 & 0.823 & 0.747 & $0.092^{*}$ \\
\hline \multirow[t]{2}{*}{ sm47 } & Parents & 25 & 4 & 0.494 & 0.360 & $0.275^{* * *}$ \\
\hline & Offspring & 393 & 8 & 0.464 & 0.371 & $0.200 * * *$ \\
\hline \multirow[t]{2}{*}{$\operatorname{sm} 51$} & Parents & 25 & 7 & 0.722 & 0.600 & $0.171^{\mathrm{ns}}$ \\
\hline & Offspring & 396 & 14 & 0.723 & 0.677 & $0.064 * * *$ \\
\hline \multirow[t]{2}{*}{ Over all loci } & Parents & 25 & 9.2 & 0.799 & 0.740 & $0.068 * * *$ \\
\hline & Offspring & 395 & 14.2 & 0.790 & 0.723 & $0.085 * * *$ \\
\hline
\end{tabular}

$\mathrm{N}$, number of individuals; A, number of alleles; He, expected heterozygosity; Ho, observed heterozygosity; f, inbreeding coefficient Significance levels: ${ }^{\mathrm{ns}} p>0.05, * p<0.05, * * p<0.01, * * * p<0.001$ 
among offspring seedlings or adults for any of the eight loci. The inbreeding coefficients for all eight loci were significantly positive for offspring seedlings, suggesting an excess of homozygous individuals at this stage, whereas only two loci showed significant positive departures from Hardy-Weinberg proportions for adults. Over all loci, the inbreeding coefficient was significantly positive for adults and offspring seedlings, pointing to an overall heterozygote deficiency at both stages if the sampled population is considered to be a single panmitic unit. The inbreeding coefficient in offspring seedlings was slightly higher than in adults $(f=0.085$ and 0.068 , respectively), suggesting weak (or no) selection favouring heterozygotes from seed to the adult stage.

\section{Mating system}

The studied population of Swietenia macrophylla exhibited a predominantly outcrossed mating system $\left(t_{m}=0.938\right.$; mean $\left.t_{s}=0.821\right)$. The values of $t_{s}$ for each locus were consistently lower than $t_{m}$, except for locus sm31 (Table 2).

Multi-locus outcrossing rates for individual trees varied from 0.39 to 1.00 (Table 3). The inbreeding in the population was concentrated mainly in two trees (\#3 and \#18, $t_{m}=0.50$ and 0.39), whereas the remaining trees were highly or fully outcrossed. Direct genotypic data analysis from the progeny arrays showed that 373 seedlings $(93.25 \%$ of the total) unambiguously resulted from outcrossed

Table 2 Single-locus $\left(t_{s}\right)$ and multi-locus $\left(t_{m}\right)$ outcrossing rate estimates, index of correlated matings $\left(r_{p}\right)$, and maximum likelihood estimates of ovule and pollen frequency of the most matings, exhibiting at least one locus with a different allele from those present in the maternal parent. The remaining 27 seedlings had genotypes consistent with a self-fertilisation origin, but may also result from outcrossing to an individual having a similar genotype. However, cryptic outcrossing was very unlikely in this study due to the highly polymorphic microsatellite loci used in the analysis. Apomixis was ruled out in this population of $S$. macrophylla since none of the 400 seedlings had a multi-locus genotype identical to its mother tree. The multi-locus correlation of paternity (probability that siblings shared the same father) within the progeny arrays in the population was $r_{p}=0.428 \pm 0.055$, suggesting that seeds within a capsule were, on average, sired by $2-3$ outcross pollen donors, calculated as the inverse of $r_{p}$ (Ritland 1989). Estimates of $r_{p}$ at the family level were highly variable (ranging from 0.044 to 0.803 ), suggesting that the paternal mating pool among families usually varies from one to seven male parents, but in a few families the number of pollen donors may be higher than 20 .

\section{Discussion}

\section{Sampling}

In order to standardise our sampling among the 25 open-pollinated families, we sowed all seeds from one capsule collected directly from the crown of each

common allele, for Swietenia macrophylla at Marajoara, southeastern Amazonia, Brazil

\begin{tabular}{lrrrr}
\hline Locus & \multicolumn{1}{c}{$t_{s}$} & $r_{p}$ & Ovule & Pollen \\
\hline sm01 & $0.835(0.020)$ & $0.398(0.042)$ & $0.180(0.050)$ & $0.141(0.046)$ \\
sm22 & $0.737(0.032)$ & $0.406(0.054)$ & $0.300(0.070)$ & $0.288(0.024)$ \\
sm31 & $0.884(0.017)$ & $0.391(0.037)$ & $0.180(0.050)$ & $0.224(0.018)$ \\
sm32 & $0.796(0.023)$ & $0.397(0.041)$ & $0.180(0.046)$ & $0.166(0.021)$ \\
sm40 & $0.730(0.027)$ & $0.541(0.063)$ & $0.440(0.066)$ & $0.329(0.031)$ \\
sm46 & $0.859(0.027)$ & $0.453(0.052)$ & $0.280(0.070)$ & $0.236(0.020)$ \\
sm47 & $0.502(0.040)$ & $0.326(0.080)$ & $0.649(0.033)$ & $0.680(0.050)$ \\
sm51 & $0.897(0.031)$ & $0.445(0.049)$ & $0.380(0.072)$ & $0.427(0.024)$ \\
Average & $t_{s}=0.821(0.011)$ & & & \\
Multi-locus & $t_{m}=0.938(0.009)$ & $r_{p}=0.429(0.020)$ & & \\
& $t_{m}-t_{s}=0.117(0.011)$ & & & \\
\hline
\end{tabular}

Standard deviations are shown in parentheses 
Table 3 Number and proportion of unambiguous outcrossed seedlings, estimates of outcrossing rate $\left(t_{m}\right)$, correlation of paternity $\left(r_{p}\right)$, and number of pollen donors per capsule (n) for 25 open-pollinated families of Swietenia macrophylla at Marajoara, south-eastern Amazonia, Brazil

\begin{tabular}{|c|c|c|c|c|c|c|}
\hline Family & $\begin{array}{l}\text { Number } \\
\text { of } \\
\text { seedlings }\end{array}$ & $\begin{array}{l}\text { Number of } \\
\text { unambiguous } \\
\text { crossed } \\
\text { seedlings }\end{array}$ & $\begin{array}{l}\text { Proportion of } \\
\text { unambiguous } \\
\text { crossed } \\
\text { seedlings }\end{array}$ & $t_{m}(\mathrm{SE})$ & $r_{p}(\mathrm{SE})$ & $\mathrm{n}\left(1 / r_{p}\right)$ \\
\hline 1 & 16 & 16 & 1.000 & $0.987(0.005)$ & $0.643(0.076)$ & 1.6 \\
\hline 2 & 16 & 16 & 1.000 & $0.987(0.006)$ & $0.493(0.123)$ & 2.0 \\
\hline 3 & 16 & 5 & 0.312 & $0.498(0.027)$ & $0.231(0.063)$ & 4.3 \\
\hline 4 & 16 & 16 & 1.000 & $0.987(0.006)$ & $0.601(0.054)$ & 1.7 \\
\hline 5 & 16 & 16 & 1.000 & $0.987(0.005)$ & $0.044(0.010)$ & 22.7 \\
\hline 6 & 16 & 14 & 0.875 & $0.878(0.001)$ & $0.209(0.081)$ & 4.8 \\
\hline 7 & 16 & 16 & 1.000 & $0.987(0.006)$ & $0.093(0.028)$ & 10.8 \\
\hline 8 & 16 & 16 & 1.000 & $0.987(0.006)$ & $0.182(0.059)$ & 5.5 \\
\hline 9 & 16 & 15 & 0.937 & $0.948(0.009)$ & $0.339(0.107)$ & 2.9 \\
\hline 10 & 16 & 16 & 1.000 & $0.987(0.006)$ & $0.496(0.085)$ & 2.0 \\
\hline 11 & 16 & 16 & 1.000 & $0.987(0.006)$ & $0.597(0.113)$ & 1.7 \\
\hline 12 & 16 & 16 & 1.000 & $0.987(0.006)$ & $0.443(0.072)$ & 2.3 \\
\hline 13 & 16 & 16 & 1.000 & $0.987(0.006)$ & $0.117(0.042)$ & 8.5 \\
\hline 14 & 16 & 16 & 1.000 & $0.987(0.006)$ & $0.238(0.076)$ & 4.2 \\
\hline 15 & 16 & 14 & 0.875 & $0.878(0.001)$ & $0.072(0.030)$ & 13.9 \\
\hline 16 & 16 & 16 & 1.000 & $0.987(0.006)$ & $0.302(0.060)$ & 3.3 \\
\hline 17 & 16 & 16 & 1.000 & $0.987(0.005)$ & $0.803(0.014)$ & 1.2 \\
\hline 18 & 16 & 5 & 0.312 & $0.389(0.035)$ & $0.238(0.086)$ & 4.2 \\
\hline 19 & 16 & 16 & 1.000 & $0.987(0.005)$ & $0.084(0.083)$ & 11.9 \\
\hline 20 & 16 & 16 & 1.000 & $0.987(0.006)$ & $0.148(0.050)$ & 6.8 \\
\hline 21 & 16 & 16 & 1.000 & $0.987(0.005)$ & $0.316(0.061)$ & 3.2 \\
\hline 22 & 16 & 16 & 1.000 & $0.987(0.006)$ & $0.567(0.099)$ & 1.8 \\
\hline 23 & 16 & 16 & 1.000 & $0.987(0.006)$ & $0.176(0.054)$ & 5.7 \\
\hline 24 & 16 & 16 & 1.000 & $0.987(0.006)$ & $0.143(0.048)$ & 7.0 \\
\hline 25 & 16 & 16 & 1.000 & $0.987(0.006)$ & $0.173(0.061)$ & 7.0 \\
\hline
\end{tabular}

mother tree, choosing randomly after germination 16 seedlings per family for the genetic analysis. The highly standardised sampling effort used here contrasts with those used in most other published studies on mating systems of tropical trees where no standardised sampling procedure was used-usually there are vague descriptions of seed collection made "beneath the trees" or "from the crown" with no clarification about the number of fruits involved in the progeny analysis. Even though the sampling method used here ensures equivalent among-family comparisons, it is nevertheless likely that this method underestimated the number of pollen donors per progeny array since each capsule is formed from the fertilisation of a single flower. Caution is therefore necessary when comparing the size of paternal mating pools among different tropical tree species due to the diverse sampling regimes used in mating system studies.

Genetic diversity in adults and seeds

An excess of heterozygotes has often been reported for natural populations of temperate trees (Bush and Smouse 1992) and for some tropical trees (Eguiarte et al. 1992; Doligez and Joly 1996), whereas a significant excess of homozygotes among adult trees has rarely been found (but see Gibson and Wheelwright 1995; White et al. 1999). The excess of homozygous seeds in Swietenia macrophylla for a high proportion of the loci, despite a high outcrossing rate, is likely to have arisen via self-fertilisation in a few individuals and/or correlated matings (see below). This homozygote excess suggests some level 
of self-compatibility and/or weak selection against homozygous zygote genotypes. The slightly higher inbreeding coefficient in seeds than in adults could also be a reflection of an increase in the selfing rate produced in the population subsequent to logging, but further evidence is necessary for this conclusion since no pre-logging estimate is available.

The inbreeding coefficient found in the adult cohort $(f=0.076)$ is considerably higher than that expected if the inbreeding was only due to selfing $\left(f_{e q}=1-t / 1+t=0.031\right)$, suggesting that this population is likely to have experienced higher levels of inbreeding in the past and has not yet reached an inbreeding equilibrium. The high proportion of homozygous genotypes in the adult stage, although less than in the seed generation, also suggests that selection against inbred seedlings and juveniles, if any, seems not to be strong enough to totally overcome the excessive production of homozygous seeds by maternal trees. The presence of null alleles has been detected in microsatellite markers and has also been cited as a possible cause for deficiency of heterozygotes (Jarne and Lagoda 1996). As no mismatches between progeny and maternal tree were detected for the eight microsatellite loci assayed among the 25 families, it is unlikely that null alleles had any influence on the estimate of homozygote proportions in the Marajoara population.

The ability to reproduce by selfing may be advantageous for tree species that disperse seeds into spatially and temporally unpredictable environments such as open areas formed by tree-fall gaps, blowdowns or landslides (Murawski et al. 1994). The clumped distribution of $S$. macrophylla trees at Marajoara reflects the adaptation by the species to colonise gaps created by canopy disturbances occurring at a higher frequency on low ground compared to high ground, coupled with more nutrient-rich soils along seasonal streams (Grogan et al. 2003; Grogan and Galvão 2006). Swietenia macrophylla populations established in new areas are likely to have experienced demographic bottlenecks due to the putative small number of founders following successful establishment. Previous theories predict that after demographic bottlenecks and/or prolonged inbreeding, most deleterious recessive mutations would be exposed to selection and purged from inbred populations, reducing the genetic load (Lande and Schemske 1985; Uyenoyama 1986). A plausible explanation for the current excess of homozygous trees and the putative weak selection against homozygotes observed for this population may therefore be that individuals with lower levels of detrimental recessive or lethal mutations (and consequently, with more tolerance for selfing) have adaptive advantages during sporadic colonisation events.

It is noteworthy that another mahogany species from Central America with similar life history traits, Swietenia humilis Zucc., also exhibited a significant deficit of heterozygotes among adult trees using microsatellites (White and Boshier 2000). In contrast, populations of two other Meliaceae species, Carapa procera D. C. and C. guianensis Aubl., with distinct life history traits (animal-dispersed seeds, shade tolerant juveniles, adults reaching mid-canopy height, climax species) showed no departure from HardyWeinberg genotypic proportion (Hall et al. 1994; Doligez and Joly 1996; Dayanandan et al. 1999). The data available so far therefore suggest that the source of heterozygote deficits in pioneer, gap-colonist Meliaceae species might be the founder effects and population bottlenecks experienced by these populations during the colonisation process, when the rate of selfing or the levels of correlated matings normally increase even in non-selfing organisms (Wright 1921).

\section{Mating system}

Swietenia macrophylla trees in the Marajoara population are completely or predominantly outcrossed (23 out of 25), agreeing with data for the majority of Neotropical rain forest tree species investigated so far (Ward et al. 2005). The high multi-locus outcrossing found for Swietenia macrophylla (this study and Loveless and Gullison 2003) was similar to those recorded for the neotropical Meliaceae species Cedrela odorata L. (James et al. 1998), Carapa guianensis (Hall et al. 1994; Cloutier et al. 2007) and Swietenia humilis (White and Boshier 2000), but considerably higher than the one found for Carapa procera $\left(t_{m}=0.78\right.$, Doligez and Joly 1997) in French Guyana.

Estimated values of $t_{m}$ among families were not evenly distributed among maternal trees, implying that the degree of self-incompatibility, or the level of dichogamy-the temporal separation between pollen exposition and stigma receptivity—may be variable 
among individuals. A wide range in individual outcrossing rates has also been observed in other Neotropical tree species such as Ceiba pentandra L. Gaetrn., Cavallinesia platanifolia (H. \& B.) H. B. K. (Murawski and Hamrick 1992a, b; Murawski et al. 1990), Cariniana legalis (Mart.) Kuntze (Sebbenn et al. 2000), and Dinizia excelsa Ducke (Dick 2001). Like S. macrophylla, these are late successional species whose light-demanding juveniles colonise large gaps, with long-lived adults persisting in mature forest as emergent trees. Tropical trees belonging to this ecological class probably have plastic mating systems allowing isolated individuals to eventually set seeds after colonising large gaps.

The significant excess of homozygote seeds and considerable biparental mating provide evidence of inbred mating in S. macrophylla at the Marajoara site. Both mating parameters suggest that gametes are not uniting totally at random from adults to seed generations, probably due to factors such as selffertilisation coupled with correlated mating. Given that $S$. macrophylla is a monoecious species, selfpollination is possible. Monoecism may enhance outbreeding, but not as effectively as dioecism or as an efficient self-incompatibility mechanism. Although temporal separation between anthesis of male and female flowers has been cited in the Meliaceae at the inflorescence level (Styles 1972), some overlap in flowering times of the two sexes apparently occurs on individual trees (White and Boshier 2000) which may allow self-pollination.

The relatively large difference between the multilocus and single locus estimates $\left(t_{m}-t_{s}=0.117\right)$ provides evidence that, despite the high outcrossing rate, a considerable degree of inbreeding of biparental origin (caused by correlated matings) contributed to the levels of genetic variation of the seed population. The relatively high bi-parental inbreeding suggests a spatial genetic structure among adult trees. Assortative mating would instead reflect tighter synchrony in flowering phenology between genetically related individuals, as suggested for Carapa procera (Doligez and Joly 1996). Further studies comparing flowering phenology and demographic genetics are necessary to test these hypotheses.

The small and variable size of the paternal mating pool among families (i.e. the number of pollen donors siring seeds per capsule) may reflect combined ecological and demographic factors such as variable density of remnant adult trees in the logged population, asynchronous flowering, pollen competition, and limited pollinator foraging. However, an increase in the number of pollen donors per progeny would be expected if sib-pairs were sampled from different capsules on the same tree, since these capsules would likely be derived from flowers pollinated on different days.

Outcrossing measures based on direct observation of the number of outcrossers provide a reliable and useful indication of the minimum number of outcrossed progeny (Shaw et al. 1981; Brown et al. 1985), despite the simplistic approach. When a large number of highly polymorphic loci are used, as in the current study of $S$. macrophylla, it is likely that the detected outcrossing represents a close estimate of the actual outcrossing. Owing to the high paternity exclusion probability (Weir 1996) of the eight microsatellite loci used here $(p>0.999$, Lemes et al. 2002), the fraction of undetected (cryptic) outcross progeny was probably very low.

Overall, this population of $S$. macrophylla seems to have adaptations that preferentially produce outcrossed progeny but also allow for selfing. Around $80 \%$ of maternal trees had $100 \%$ of seeds in the sampled fruit resulting from outcrossing. Despite the high outcrossing rate, the potential for inbreeding was not negligible. Some fruit capsules had a considerable proportion $(>60 \%)$ of selfed seeds, suggesting variable degrees of self-incompatibility (or different levels of dichogamy) among individuals.

\section{Conclusions}

The findings described here on the mating system of Swietenia macrophylla have important consequences for the conservation biology and management of the species. Owing to its generalist pollination system and some level of tolerance for selfing, S. macrophylla appears very resilient to environmental disturbances, setting fruit and seed even at low densities of adult trees. Although the impact of logging on seed output remains an unanswered question, the surviving trees in the Marajoara population have maintained their capacity to set fruit annually, with predominantly outcrossed seeds, even in a logged area where tree density dropped to $16 \%$ of the original population. It appears that $S$. macrophylla has a plastic pollination 
system and that logging has not disrupted pollen movement among remnants trees in the Marajoara population. In fact, fruit- and seed-set in S. macrophylla have been observed in anthropogenic landscapes located outside of its natural distribution, such as in the urban areas of Brasília in central Brazil and Manaus in central Amazonia.

Despite the high genetic diversity observed within S. macrophylla populations in Brazilian Amazonia and Central America (Lemes et al. 2003; Novick et al. 2003), this species demonstrates some levels of inbreeding as suggested by the excess of homozygotes found among adult trees and by the proportion of selfed offspring in some progeny arrays. These traits, likely reflecting the gap-colonist life history of S. macrophylla, suggest that population reductions due to logging and fragmentation may not seriously affect the reproductive potential of all remaining individuals. This is likely the case with most tropical rain forest tree species, which probably retain high genetic loads (Alvarez-Buylla et al. 1996). Moreover, since the pollen and seed vectors of S. macrophyllawidespread small generalist insects and wind, respectively-are unlikely to be heavily affected by logging activities, pollination and dispersal capabilities will persist even in these exploited and disturbed areas. A similarly resilient mating system was found for the congeneric $S$. humilis in a degraded and fragmented landscape in Central America (White et al. 2002).

Many of the remaining trees in logged areas and relict fragments may persist as reproductively viable individuals and would therefore be very important both for future natural and artificial regeneration and for long-term population recovery and genetic conservation programmes. Intensive logging followed by forest conversion to pastures and extensive plantations (e.g., soybean) as has been occurring at alarming rates throughout Brazilian Amazonia, remains the primary short-term threat to the maintenance of $S$. macrophylla populations. On the other hand, low-intensity logging which retains some proportion of reproductive trees, followed by activities that conserve forest cover (e.g. extraction of non-timber forest products, agroforestry) and accelerate natural or silviculturally induced $S$. macrophylla regeneration, may represent the best strategy for combining conservation and economic use of Brazilian mahogany in areas with increasing human pressure.
Acknowledgements This study was part of the $\mathrm{PhD}$ thesis by the first author at the University of Stirling, UK, and was funded by the Brazilian Ministry of Science and Technology (CNPq/PADCT grant no. 62.00059/97-4 to D.G., CNPq/RHAE fellowship no. 260021/94.6 to M.R.L), World Wildlife Fund (Grant no. CSR 95-033 to M.R.L), and by the Fundação Botânica Margaret Mee. We also acknowledge partial financial support from the European Commission, DG-XII, International Cooperation with Developing Countries Programme, contract number ERBIC18CT970149. Additional support was provided by the USDA Forest Service International Institute of Tropical Forestry and USAID Brazil. Infrastructural support was provided by the timber export companies Serraria Marajoara Ltd (SEMASA) and Madeireira Juary. We thank José Ribeiro for field assistance and Laszlo Nagy for helpful comments and revision of the manuscript.

\section{References}

Alvarez-Buylla ER, García-Barros R, Lara-Moreno C et al (1996) Demographic and genetic models in conservation biology: applications and perspectives for tropical rain forest tree species. Annu Rev Ecol Syst 27:387-421

Barrett SCH, Husband BC (1990) The genetics of plant migration and colonization. In: Brown AHD, Clegg MT, Kahler AL et al (eds) Plant population genetics, breeding, and genetic resources. Sinauer, Sunderland

Bawa KS (1990) Plant-pollinator interactions in tropical rain forests. Annu Rev Ecol Syst 20:399-422

Boshier DH, Chase MR, Bawa KS (1995) Population genetics of Cordia alliadora (Boraginaceae), a Neotropical tree. 2. Mating system. Am J Bot 82:476-483

Brown AHD, Barrett SCH, Moran GF (1985) Mating system estimation in forest trees: models, methods and meanings. In: Gregorius HR (eds) Population genetics in forestry. Springer, Berlin, Heidelberg, New York

Bush RM, Smouse PE (1992) Evidence for the adaptive significance of allozymes in forest trees. New Forest 6: 179-196

Cloutier D, Kanashiro M, Ciampi AY et al (2007) Impact of selective logging on inbreeding and gene dispersal in an Amazonian tree population of Carapa guianensis Aubl. Mol Ecol 16:797-809

Dayanandan S, Dole J, Bawa K et al (1999) Population structure delineated with microsatellite markers in fragmented populations of a tropical tree, Carapa guianensis (Meliaceae). Mol Ecol 10:1585-1592

Dick CW (2001) Genetic rescue of remnant tropical trees by an alien pollinator. Proc R Soc Lond B 268:2391-2396

Doligez A, Joly HI (1996) Genetic diversity and spatial structure within a natural stand of a tropical forest tree species, Carapa procera (Meliaceae), in French Guyana. Heredity 79:72-82

Doligez A, Joly HI (1997) Mating system of Carapa procera (Meliaceae) in the French Guyana tropical forest. Am J Bot 84:461-470

Doyle JJ, Doyle JL (1987) Isolation of plant DNA from fresh tissue. Focus 12:13-15

Eguiarte LE, Perez-Nasser N, Piñero D (1992) Genetic structure, outcrossing rate and heterosis in Astrocaryum 
mexicanum (tropical palm): implications for evolution and conservation. Heredity 69:217-228

Federov AA (1966) The structure of the tropical rain forest and speciation in the humid tropics. J Ecol 54:1-11

Gibson JP, Wheelwright NT (1995) Genetic structure in a population of a tropical tree Ocotea tenera (Lauraceae): influence of avian seed dispersal. Oecologia 103:49-54

Gillies ACM, Navarro C, Lowe AJ et al (1999) Genetic diversity in Mesoamerican populations of mahogany (Swietenia macrophylla), assessed using RAPDs. Heredity 83:722-732

Gribel R, Gibbs PE, Queiroz AL (1999) Flowering phenology and pollination biology of Ceiba pentandra (Bombacaceae) in Central Amazonia. J Trop Ecol 15: 247-263

Grogan J, Barreto P (2005) Big-leaf mahogany on CITES Appendix II: big challenge, big opportunity. Conserv Biol 19:973-976

Grogan J, Galvão J (2006) Physiographic and floristic gradients across topography in transitional seasonally dry evergreen forests of southeastern Amazonia, Brazil. Act Amazon 36:483-496

Grogan J, Ashton MS, Galvão J (2003) Big-leaf mahogany (Swietenia macrophylla) seedling survival and growth across a topographic gradient in southeast Pará, Brazil. For Ecol Manage 186:311-326

Grogan J, Jennings SB, Landis RM et al (in press) What loggers leave behind: mahogany population structure and potential for recovery in the Brazilian Amazon. For Ecol Manage

Guo SW, Thompson EA (1992) Performing the exact test for Hardy-Weinberg proportions for multiple alleles. Biometrics 48:2868-2872

Hall P, Orrel LC, Bawa KS (1994) Genetic diversity and mating system in a tropical tree, Carapa guianensis (Meliaceae). Am J Bot 81:1104-1111

James T, Vege S, Aldrich P (1998) Mating systems of three tropical dry forest tree species. Biotropica 30:587-594

Jarne P, Lagoda PJL (1996) Microsatellites, from molecules to populations and back. TREE 11:424-429

Lande R, Schemske DW (1985) The evolution of self-fertilization and inbreeding depression in plants. I. Genetics models. Evolution 39:24-40

Lemes MR, Brondani RPV, Grattapaglia D (2002) Multiplexed systems of microsatellite markers for genetic analysis in mahogany, Swietenia macrophylla King (Meliaceae), a threatened Neotropical timber species. J Hered 93:287291

Lemes MR, Gribel R, Proctor J et al (2003). Population genetic structure of mahogany (Swietenia macrophylla King, Meliaceae) across the Brazilian Amazon, based on variation at microsatellite loci: implications for conservation. Mol Ecol 12:2875-2883

Loveless MD, Gullison RE (2003) Genetic variation in mahogany populations in Bolivia. In: Lugo AE, Figueroa Colon JC, Alayon M (eds) Big-leaf mahogany: genetics, ecology, and management. Springer-Verlag, New York

Loveless MD, Hamrick JL, Foster RB (1998) Population structure and mating system in Tachigali versicolor, a monocarpic Neotropical tree. Heredity 81:134-143
Murawski DA, Hamrick JL (1991) The effect of the density of flowering individuals on the mating systems of nine tropical tree species. Heredity 67:167-174

Murawski DA, Hamrick JL (1992a) The mating system of Cavanillesia platanifolia under extremes of flowering-tree density: a test of predictions. Biotropica 24:99-101

Murawski DA, Hamrick JL (1992b) Mating system and phenology of Ceiba pentandra (Bombacaceae) in Central Panama. J Hered 83:401-404

Murawski DA, Hamrick JL, Hubbell SP et al (1990) Mating systems of two Bombacaceous trees of a Neotropical moist forest. Oecologia 82:501-506

Murawski DA, Dayanandan B, Bawa KS (1994) Outcrossing rates of two endemic Shorea species from Sri Lankan tropical rain forests. Biotropica 26:23-29

Novick RR, Dick CW, Lemes MR et al (2003) Genetic structure of Mesoamerican populations of big-leaf mahogany (Swietenia macrophylla) inferred from microsatellite analyses. Mol Ecol 12:2885-2893

Raymond M, Rousset F (1998) GENEPOP (version 3.1c) an updated version of GENEPOP V.1.2 (1995): population genetics software for exact tests and ecumenicism. J Hered 86:248-249

Ribeiro RA, Lovato MB (2004) Mating system in a neotropical tree species, Senna multijuga (Fabaceae). Gen Mol Biol 27:418-424

Ritland K (1983) Estimation of mating systems. In: Tanksley $\mathrm{D}$, Orton TJ (eds) Isozymes in plant breeding and genetics, part A. Elsevier, Amsterdam

Ritland K (1988) The genetic-mating structure of subdivided populations II. Correlated mating models. Theor Popul Biol 34:320-346

Ritland K (1989) Correlated matings in the partial selfer $M i$ mulus guttatus. Evolution 43:848-859

Ritland K (2002) Extensions of models for the estimation of mating systems using $n$ independent loci. Heredity 88:221-228

Ritland K, El-Kassaby YA (1985) The nature of inbreeding in a seed orchard of Douglas-fir as shown by an efficient multilocus model. Theor Appl Gen 71:375-384

Ritland K, Jain SK (1981) A model for the estimation of outcrossing rate and gene frequencies based on $\mathrm{n}$ independent loci. Heredity 47:37-54

Sebbenn AM, Kageyama PY, Siqueira ACMF et al (2000) Mating system in populations of Cariniana legalis Mart. O. Ktze: implications for genetic conservation and improvement. Scientia Forestalis 58:25-40

Shaw DV, Kahler AL, Allard RW (1981) A multilocus estimator of mating system parameters in plant populations. Proc Natl Acad Sci USA 78:1298-1302

Styles BT (1972) The flower biology of the Meliaceae and its bearing on tree breeding. Silvae Gen 21:175-182

Uyenoyama MK (1986) Inbreeding and the cost of meiosis: the evolution of selfing in populations practising biparental inbreeding. Evolution 40:388-404

Ward M, Dick CW, Gribel R et al (2005) To self, or not to self...A review of outcrossing and pollen-mediated gene flow in neotropical trees. Heredity 95:246-254

Weir BS (1996) Genetic data analysis II. Sinauer Associates, Sunderland 
Weir BS, Cockerham CC (1984) Estimating F-statistics for the analysis of population structure. Evolution 38:13581370

White GM, Boshier DH (1999) Genetic variation within a fragmented population of Swietenia humilis Zucc. Mol Ecol 11:1899-1910

White GM, Boshier DH (2000) Fragmentation in Central American dry forests-genetic impacts on Swietenia humilis. In: Young AG, Clarck G (eds) Genetics, demography and the viability of fragmented populations. Cambridge University Press, Cambridge

White GM, Boshier DH, Powell W (2002) Increased pollen flow counteracts fragmentation in a tropical dry forest: an example from Swietenia humilis Zuccarini. Proc Natl Acad Sci USA 99:2038-2042

Wright S (1921) Systems of mating II. The effects of inbreeding on the genetic composition of a population. Genetics 6:124-143 